\title{
The Proceedings of the International Conference
}

on Creationism

Volume 8

Print Reference: Pages 695-706

Article 13

2018

\section{Effect of Aerosol Distributions on Precipitation Patterns Needed for a Rapid Ice Age}

Steven M. Gollmer

Cedarville University

Follow this and additional works at: https://digitalcommons.cedarville.edu/icc_proceedings

Part of the Atmospheric Sciences Commons, Climate Commons, and the Physics Commons

DigitalCommons@Cedarville provides a publication platform for fully open access journals, which means that all articles are available on the Internet to all users immediately upon publication. However, the opinions and sentiments expressed by the authors of articles published in our journals do not necessarily indicate the endorsement or reflect the views of DigitalCommons@Cedarville, the Centennial Library, or Cedarville University and its employees. The authors are solely responsible for the content of their work. Please address questions to dc@cedarville.edu.

Browse the contents of this volume of The Proceedings of the International Conference on Creationism.

\section{Recommended Citation}

Gollmer, S.M. 2018. Effect of aerosol distributions on precipitation patterns needed for a rapid Ice Age. In Proceedings of the Eighth International Conference on Creationism, ed. J.H. Whitmore, pp. 695-706.

Pittsburgh, Pennsylvania: Creation Science Fellowship. 


\title{
EFFECT OF AEROSOL DISTRIBUTIONS ON PRECIPITATION PATTERNS NEEDED FOR A RAPID ICE AGE
}

\author{
Steven M. Gollmer, Cedarville University, 251 N. Main St., Cedarville, OH 45314, gollmers@cedarville.edu
} ABSTRACT

Introduced in the Genesis Flood by Whitcomb and Morris (1961) and fleshed out by Oard (1979) a model for an ice age in the wake of the Genesis flood was used to explain the evidence of glaciation in Canada and the United States without resorting to eons of time. It was proposed that this rapid ice age was the consequence of post flood warm oceans, barren land and volcanic aerosols. The impact of warm oceans was simulated by Vardiman (1998) and Gollmer (2013) using climate models. Although warm oceans increase precipitation in the Arctic, global surface temperatures become unbearably hot unless volcanic aerosols equivalent to the eruption of Toba are used. In addition, with ocean temperatures of $30^{\circ} \mathrm{C}$ the formation of snow and ice are impossible because air and land temperatures in the Arctic remain above freezing.

Using dynamic oceans with a uniform initial temperature of $24{ }^{\circ} \mathrm{C}$, climate simulations are performed to explore the impact of aerosol distributions on the position of the jet stream and storm tracks. In previous simulations, precipitation in the Arctic is primarily over the ocean rather than land, thus limiting how quickly ice sheets are able to grow. Although the simulations reported here are still too warm for the accumulation of snow, it is clear that the thermal circulation coming off a cold continent must be offset by other factors in order for sufficient precipitation to fall inland.

\section{KEY WORDS}

climate modeling, Ice age, post-Flood, warm ocean, sea-surface temperature, aerosols, precipitation, winds

\section{INTRODUCTION}

Much has been written about the Flood that occurred in the time of Noah. During the mid-nineteenth century the scriptural geologists responded to the writings of Lyell (1833) and Buckland (1858), which pulled away from a belief that there was scientific evidence for a universal flood (Mortenson, 2004). Price's The New Geology (1923) renewed interest in flood geology. However, it was the landmark book, The Genesis Flood: The Biblical Record and Its Scientific Implications (Whitcomb and Morris, 1961), that revitalized scientific scholarship related to the global flood recorded in Genesis 6-8. With a distribution over ten times that of Price's book it has shaped creationist research for the past half century.

Although a number of alternate theories have been proposed for explaining geological features, many productive hypotheses used by creationist today are delineated in this book. One hypothesis relates to Agassiz's conclusion that geological features formerly attributed to the Flood were better explained through a series of ice ages. Agassiz founded the study of glaciology with the publication of Etudes sur les glaciers (Agassiz, 1840). Whitcomb and Morris agreed that there was geological evidence for a post-flood ice age, but proposed a much shorter time frame for its occurrence. Feasibility of a rapid ice age was presented by Oard (1979) and used the mechanisms proposed by Whitcomb and Morris (warm oceans, large amounts of volcanic aerosols and denuded land from the flood). His calculations result in an ice sheet reaching a depth of over $400 \mathrm{~m}$ within a time period of 500 years. Additional details about post-flood glaciation and the rapid ice age model can be found in Oard (1990).

In order to test Oard's proposal through numerical simulation, Vardiman adapted the National Center for Atmospheric Research (NCAR) Community Climate Model 1 (CCM1) to run on a personal computer. Spelman (1996) used this model to test its sensitivity to warm oceans. Holding the surface temperature of the ocean at $30{ }^{\circ} \mathrm{C}$, Spelman observed peak precipitation rates of $40 \mathrm{~mm} /$ day near the North Pole. Vardiman (1998) reported on simulations that placed ocean hot spots over the Mid-Atlantic ridge. Enhanced precipitation occurred down-wind of the hot spots and there was an observed shift in the wind patterns. Gollmer (2013) reproduced the work done by Spelman using the Goddard Institute of Space Studies (GISS) ModelE. Although Gollmer's simulations reported half as much precipitation, this is due to averaging results over the month rather than reporting a single day statistic.

Gollmer (2013) also reported on simulations with a dynamic ocean and enhanced aerosols. Although the simulation began with a uniform temperature of $30{ }^{\circ} \mathrm{C}$ throughout the depth of the ocean, after five years the surface temperature of the polar ocean dropped to $24{ }^{\circ} \mathrm{C}$ with temperatures near $0{ }^{\circ} \mathrm{C}$ at the continental margins in the Arctic Ocean. These colder temperatures were a residual from the inability to remove land ice from the simulation. More concerning were the $40{ }^{\circ} \mathrm{C}$ sea surface temperatures near the equator. In order to offset the additional heat source provided by the warm ocean, stratospheric aerosols from volcanic eruptions were uniformly added over the globe. Aerosols trap infrared radiation from the surface, but reflect an even greater amount of solar radiation in the visible spectrum. As a result, there is a net cooling effect. Various amounts of aerosols were simulated and the conclusion was that an optical depth of 2.0 was necessary to reduce equatorial ocean temperatures to $32{ }^{\circ} \mathrm{C}$. This amount of volcanic activity corresponds to a Toba scale event sustained over multiple years. For context, it is estimated that Toba released 20x the stratospheric aerosols as the 1815 eruption of Mount Tambora, 
which resulted in the year without a summer (Robock et al., 2009; Robertson et al., 2001). It is felt that the Toba eruption of $\sim 74 \mathrm{ka}$ B.P. (by secular measures) may have initiated the most recent ice age.

Although climate simulations provide enhanced precipitation at the high latitudes due to warm oceans, this precipitation primarily falls over the ocean and near the continental boundaries. In order for ice sheets to form and grow the precipitation must penetrate the interior of the continent. One possible resolution to this problem is to use a mesoscale model that simulates weather over a region rather than the whole globe. A higher resolution model can capture the development of individual weather events, which may contribute more to ice sheet growth than sustained rates simulated at the global scale. Using this approach, Vardiman (2003) studied the development of a hypercane in the Gulf of Mexico. Vardiman and Brewer (2010a, 2010b) looked at the impact of winter storm patterns on Yosemite National Park. For such a small spatial domain, the NCAR Weather Research and Forecasting Model (WRF) was used, which simulates weather at different spatial scales. At the largest scale, which spans a region larger than the continental United States, each grid point is $27 \mathrm{~km}$ on a side. A higher resolution (9 $\mathrm{km}$ per grid point) is nested within the original and spans a region that is $2000 \mathrm{~km}$ by $1500 \mathrm{~km}$. At the highest resolution $(3 \mathrm{~km}$ per grid point) a region $650 \mathrm{~km}$ by $500 \mathrm{~km}$ is centered on Yosemite National Park. With the enhanced precipitation from warm oceans and a greater frequency of snow storm events these simulations indicate that glaciation in the Sierra Nevada can be explained in the context of the Genesis Flood and its aftermath. The WRF was used for additional studies over Yellowstone (Vardiman and Brewer, 2010c), the Middle East (Vardiman and Brewer, 2011) and the eastern United States (Vardiman and Brewer, 2012a and 2012b).

Although these simulations provide insight into the effect that warm oceans have on storm dynamics, they are limited in their time domain. Simulations with resolutions from $30 \mathrm{~km}$ to $3 \mathrm{~km}$ may effectively capture sub-grid effects missed by global models of $600 \mathrm{~km}$ resolution; however, the duration of such simulations is on the order of days and weeks. These high resolution simulations capture episodic events, but assumptions must be made as to the frequency of these occurrences and their persistence through other seasons of the year. In addition, since mesoscale models are restricted to a region, the boundaries of the model must be specified. Using a nested-grid format helps mitigate this effect; however, the $27 \mathrm{~km}$ resolution region of the WRF must be nested within a global circulation model (GCM). Therefore, it is necessary to explore how the GCM responds to warm oceans and aerosols, which in turn can be used to establish the boundaries for the WRF or some other mesoscale model.

In light of the issues raised, this paper focuses on the impact that stratospheric aerosol distribution has on global wind patterns. These winds in turn have an impact on precipitation patterns around the globe. This study will use the GISS ModelE2 AR5, which has double the resolution of AR4 used by Gollmer (2013). Since Gollmer concluded that $30^{\circ} \mathrm{C}$ oceans resulted in temperatures too high for snowfall, dynamic oceans with an initial uniform temperature of $24{ }^{\circ} \mathrm{C}$ are used with various aerosol distributions. The remainder of this paper will address the following: 1) thermal circulation and the location of precipitation, 2) description of the current model and simulations, 3) aerosol distributions and their impact on wind patterns and 4) concluding discussion.

\section{THERMAL CIRCULATION AND PRECIPITATION}

To understand the challenge associated with achieving sufficient snowfall over continental interiors it is necessary to establish the basics of global wind circulation. There are four primary forces/effects that drive the winds of the earth: gravity, pressure gradient force, Coriolis effect and friction. Although it is obvious, gravity plays both a direct and indirect role in the motion of the atmosphere. The direct role is to attract the molecules of the atmosphere towards the center of the earth. Since gas molecules have energy of motion, they do not form a puddle of liquid at the earth's surface, but an envelope of nitrogen, oxygen, water vapor and various other gasses with a height of 100's of kilometers. The density of the atmosphere is greatest near the surface and $75 \%$ of the atmosphere's mass resides within the first 16 kilometers from the earth's surface. This layer is the called the troposphere and is where most of the phenomena we call weather occurs.

Gravity has an indirect role as portions of the atmosphere warm and cool. Air over a warm surface expands and becomes less dense. As a result, gravity causes the more dense cold air to move horizontally over the warm surface and push the warm air upward. We observe that warm air rises and cold air sinks, but this is the result of gravity and the differential heating of surfaces.

On a larger scale this differential heating results in warm and cold columns of air as illustrated in Figure 1a. Since the warm air is less dense, it extends to a greater height in the atmosphere than the cold column of air. If the pressure at the top of each column is the same, it is noteworthy that pressure changes at a slower rate with height in the warm column of air than in the cold column of air. As a result, high in the atmosphere, the warm air is at a higher pressure than the cold air. The pressure difference results in a pressure gradient force directed from high to low pressure and air flows from the warm to the cold column of air. As seen in Figure 1b, once air flows from the top of the warm column to the cold column, the surface pressure of the cold column increases and becomes greater than that of the warm column. This results in a pressure gradient force at the surface, driving air from the cold to the warm column. Once cold air at the surface moves over the warm surface, it warms and becomes less dense. Warm air transported to the cold surface cools and the circulation pattern perpetuates itself.

On the global scale, differential heating causes the troposphere to be thicker at the equator than at the poles. A thermal circulation is established and we would expect a surface wind to blow from the pole to the equator and a return circulation high in the troposphere blowing from the equator to the poles. This does not occur because of the Coriolis effect and friction. The Coriolis effect is the result of Newton's first law (an object in motion maintains constant straight line motion unless acted on by a net external force) and the rotation of the earth. As winds move in a straight line, the earth's surface rotates from underneath it. As a result, it appears to someone standing on the surface that the winds are veering to the right in the Northern Hemisphere and to the left in the Southern Hemisphere. This effect along with frictional drag between the earth's surface 
and layers of air above it cause the thermal circulation to break into three circulation patterns.

The three circulation patterns are called the Hadley cell, the Ferrel cell and the polar cell as illustrated in Figure 2. The Hadley cell and polar cell behave as we would expect for a thermal circulation: cold surface air moving from the poles to the equator. This results in a cooling of the equator and a net heating of the poles as thermal energy is transported poleward. In addition, air converging at the equator from both poles forces warm humid air upward. Since temperatures decrease with altitude, water vapor in this rising air condenses into precipitation, thus releasing thermal energy high in the troposphere and transporting cool rain to the surface. This region of rising air near the equator, called the Intertropical Convergence Zone (ITCZ), produces a band of clouds that are easily observed in satellite imagery.

In the mid-latitudes the Ferrel cell forms a reverse circulation where warm air at the surface is driven to the poles. The clash of
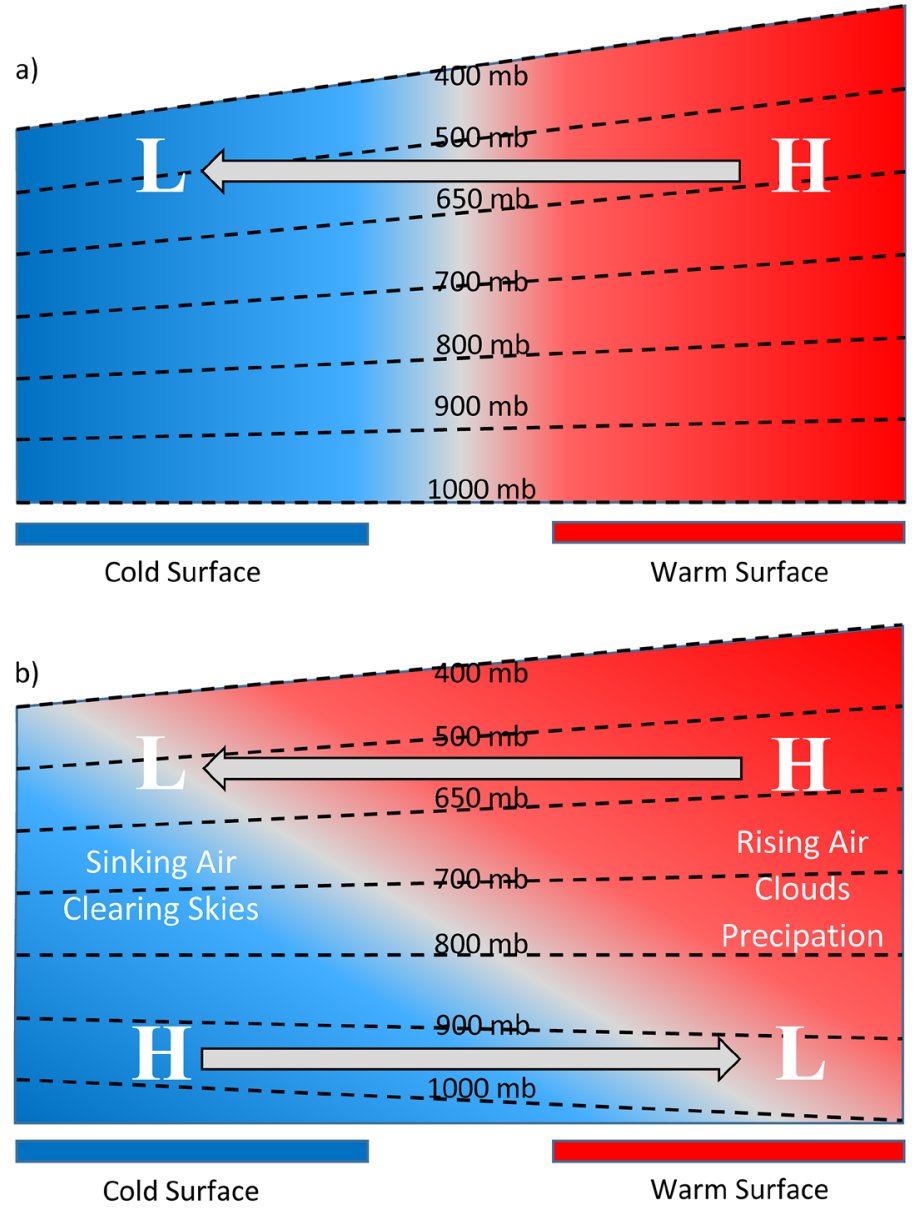

Figure 1. Thermal circulation occurs when there is a difference in surface temperature. a) Air over the warm surface occupies more volume and extends to greater altitudes than air over the cold surface. This results in a pressure gradient force high in the atmosphere that drives air from the warm to the cold column of air. b) Once warm air is transported to the top of the cold column, the surface pressure over the warm surface decreases and over the cold surface increases. This results in a pressure gradient force that drives air horizontally from the cold surface to the warm surface. This circulation pattern is perpetuated as long as a temperature difference occurs at the surface. warm air in the Ferrel cell and cold air in the Polar cell form the polar front, which is the source of severe weather and precipitation at the higher latitudes. Although this reverse circulation hinders the flow of cool, surface, polar air to the equator; instabilities in the polar front grow until cold polar air penetrates further towards the equator (trough) and warm tropical air extends further poleward (ridge). Low pressure systems along the polar front are also generated, which mix these two contrasting air masses. As a result, there is still a net flow of thermal energy poleward through the Ferrel cell.

Since the Coriolis effect veers winds to the right in the Northern Hemisphere, winds do not blow in a north-south direction. High in the troposphere in the mid-latitudes the pressure gradient force is directed northward from the warm southerly air to the cold northerly air. Since there is very little interaction of this air with the surface, friction has a minimal effect. The Coriolis effect acts perpendicular to wind direction and is proportional to wind speed.

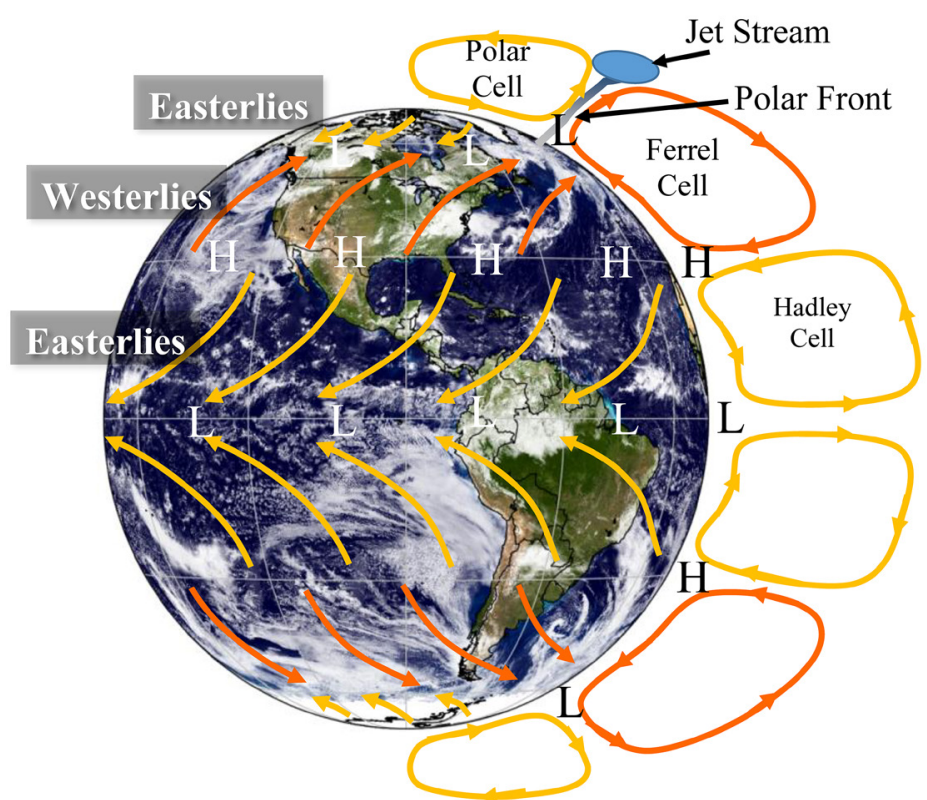

Figure 2 The global circulation pattern is a combined effect of a thermal circulation between the equator and poles, the Coriolis effect and surface friction. Both the Northern and Southern Hemispheres have a three cell circulation pattern. The Hadley cell is located closest to the equator and has winds that converge on the equator. This results in a rising band of air called the Intertropical Convergence Zone (ITCZ) and is identified from satellite images as a band of cloudiness and high precipitation. Due to the Coriolis effect the winds become easterlies as they converge near the equator. The Ferrel cell circulates opposite of what is expected from a thermal circulation, but is the result of instability generated by surface friction and the Coriolis effect. This cell has winds moving poleward from the sub-tropical high pressure located at the sinking portion of the Hadley and Ferrel cells. Surface winds in the mid-latitudes become westerlies as they approach the polar cell. The polar cell begins at the pole and has surface winds driving towards the equator. These winds are also easterlies and converge with the westerlies of the Ferrel cell. This convergence zone is called the polar front and air is forced to rise and become unstable. As a result, there is an increased probability of clouds and precipitation. Because the winds on each side of the polar front are from different directions, there is shear that produces instability in the front. As a result, the polar front can form undulations called ridges and troughs and generate low pressure storm systems. 
As the air gains speed from the pressure gradient force, it is turned to the east by the Coriolis effect until the winds blow perpendicular to the pressure gradient force. Winds where the Coriolis effect is equal and opposite to the pressure gradient force are called geostrophic winds. At the polar front, warm and cold air masses are in close proximity, thus resulting in a strong pressure gradient force. As a result, the geostrophic winds achieve high velocities and are called the jet stream. If the temperature contrast between air masses on each side of the polar front is reduced, the pressure gradient high in the troposphere is weaker resulting in weaker winds in the jet stream.

Precipitation patterns are influenced by this three cell global circulation pattern. Due to the Coriolis effect surface winds in the tropics are primarily from the east and are called the trade winds. In the mid-latitudes winds shift direction and are called the westerlies and in the polar cell they switch back to easterlies. Since oceans are a ready source of water vapor, it seems reasonable that higher rates of precipitation should occur where global winds drive humid air over continents. In the mid-latitudes Pacific air pushed up against the mountain ranges of the western United States and Canada results in high precipitation rates as illustrated in Figure 3. It is expected that the same effect should be seen on the east coast of Canada due to the polar circulation; however, the amount of water vapor in the air is smaller due to the colder North Atlantic water temperatures.

There is another thermal circulation that must be considered when dealing with warm oceans and cold continents. Although the global circulation pattern places a band of low pressure around the globe at a latitude near $60^{\circ}$, the difference in ocean/land temperatures superimposes another thermal circulation on the picture. During the summer the land is warmer than the ocean and a low pressure system resides over the land. This enhances the low pressure at the polar front and pulls humid air from the ocean over the land. However, in the winter this circulation is weakened or reversed due to the oceans being warmer than the land. The stronger the land/ocean temperature contrast the stronger the circulation and the stronger the precipitation pattern. This is clearly seen in the warm ocean simulations of Spelman (1996) and Gollmer (2013) as illustrated in Figure 4. Since the oceans are warmer than the continents in January, the rising portion of the thermal circulation is over the water, which is also where the precipitation falls.

The superposition of the global thermal circulation and continent/ ocean thermal circulation provides the big picture, which is the focus of this paper. However, it may be that additional factors will prove significant and can be the focus of future research. First, the three cell model described previously is not static, but shifts with the seasons. Although the ITCZ resides near the equator, it will shift into the Northern Hemisphere during the spring and summer months. Likewise, the location of the jet stream will move further north during the summer and further south during the winter. This transition results in volatile weather east of the Rockies in the United States during the spring and fall. Second, storm tracks are influenced by large mountain ranges, contrast in land/ocean surface roughness and location of the sub-tropical jet (a weaker jet stream occurring at the interface of the Hadley and Ferrel cells). These factors combine to situate a storm track along the eastern coast of the United States (Brayshaw et al., 2009). It could be that this storm track could draw humid air into Southern Canada and the Great Lakes region from the Atlantic Ocean.

\section{DESCRIPTION OF THE MODEL AND MODEL SIMULATIONS}

GCMs are essentially low resolution weather models used to nd Surface Winds

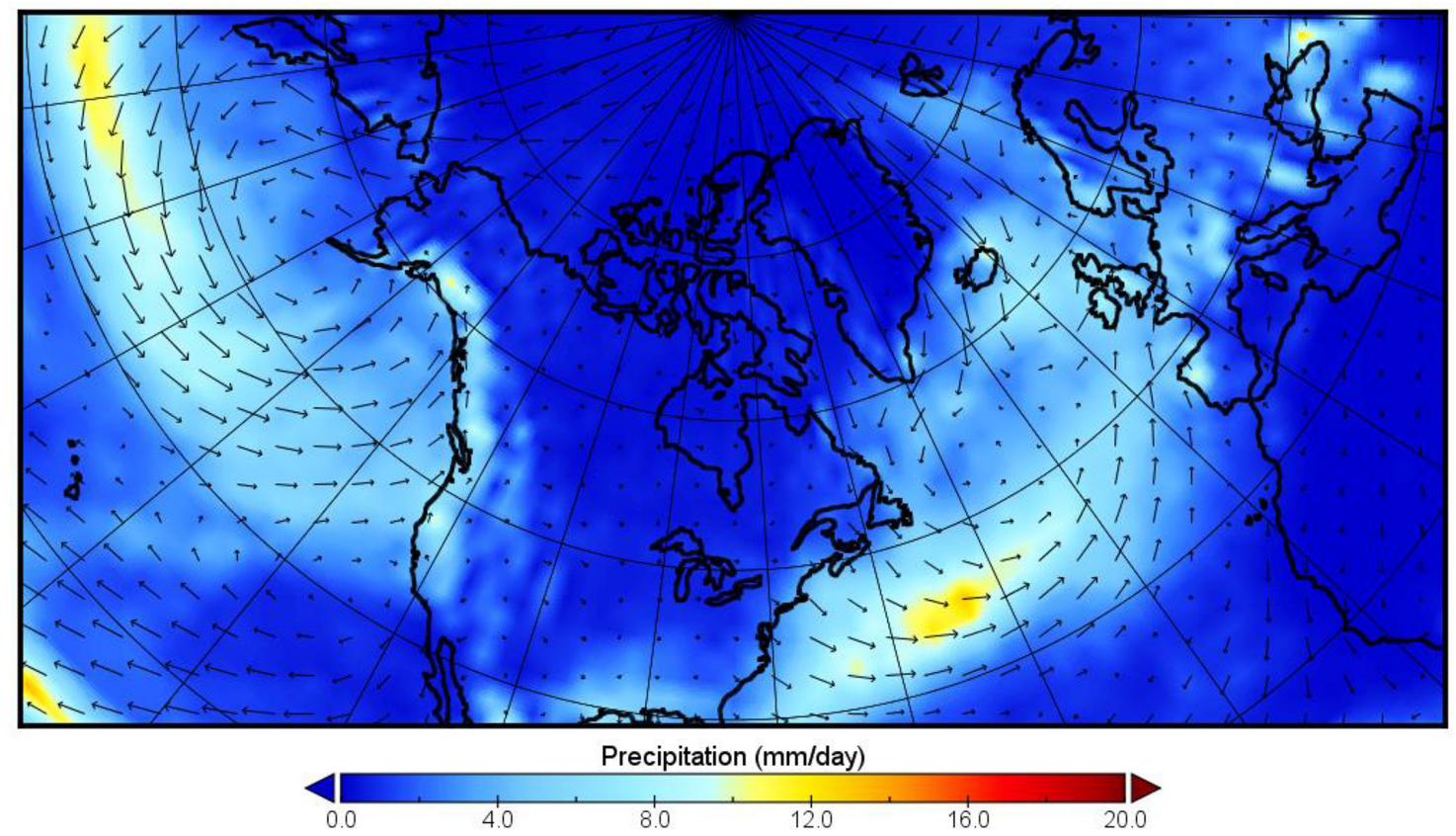

Figure 3. Precipitation and surface winds during January for the North American Continent demonstrate the connection between these two parameters. As westerly winds in the Ferrel cell move humid ocean air towards the west coast of the continent, there is precipitation that penetrates to the coastal mountains and even to the Rockies. In the polar cell, which is dominated by easterly winds, there is coastal precipitation in Labrador, New Foundland and Greenland, but not to the extent observed on the west coast. 
simulate weather over long periods of time. These models represent the earth's atmosphere as a grid of cells that cover the horizontal surface of the earth and extend through the troposphere and stratosphere (See Figure 5). Physical processes such as sun/ cloud interaction, conditions for precipitation formation and evaporation from land surfaces are represented as equations, which are used to calculate values within and between grid cells. Variables tracking pressure, temperature, momentum, density and humidity are updated at fixed time intervals. These key variables along with many others are used to describe the development of the atmosphere over time.

Reasonably accurate weather predictions can be made out to a week with such models. However, magnification of error due to the non-linear nature of the equations limits prediction of weather events at about two weeks. Although individual events cannot be predicted, statistics generated from multiple simulations or over multiple years provide insight into the long term behavior of the atmosphere. Using a lower resolution model reduces the computational requirements of each simulation. Therefore, dynamic interactions between the atmosphere, ocean and land over long periods of time can be studied using a reasonable amount of computational resources.

For this study the GISS ModelE2 AR5 is used. Development of this model began over three decades ago with the work of Hansen et al. (1983). The current version of the model was included in the Coupled Model Intercomparison Project Phase 5 (CMIP5) and
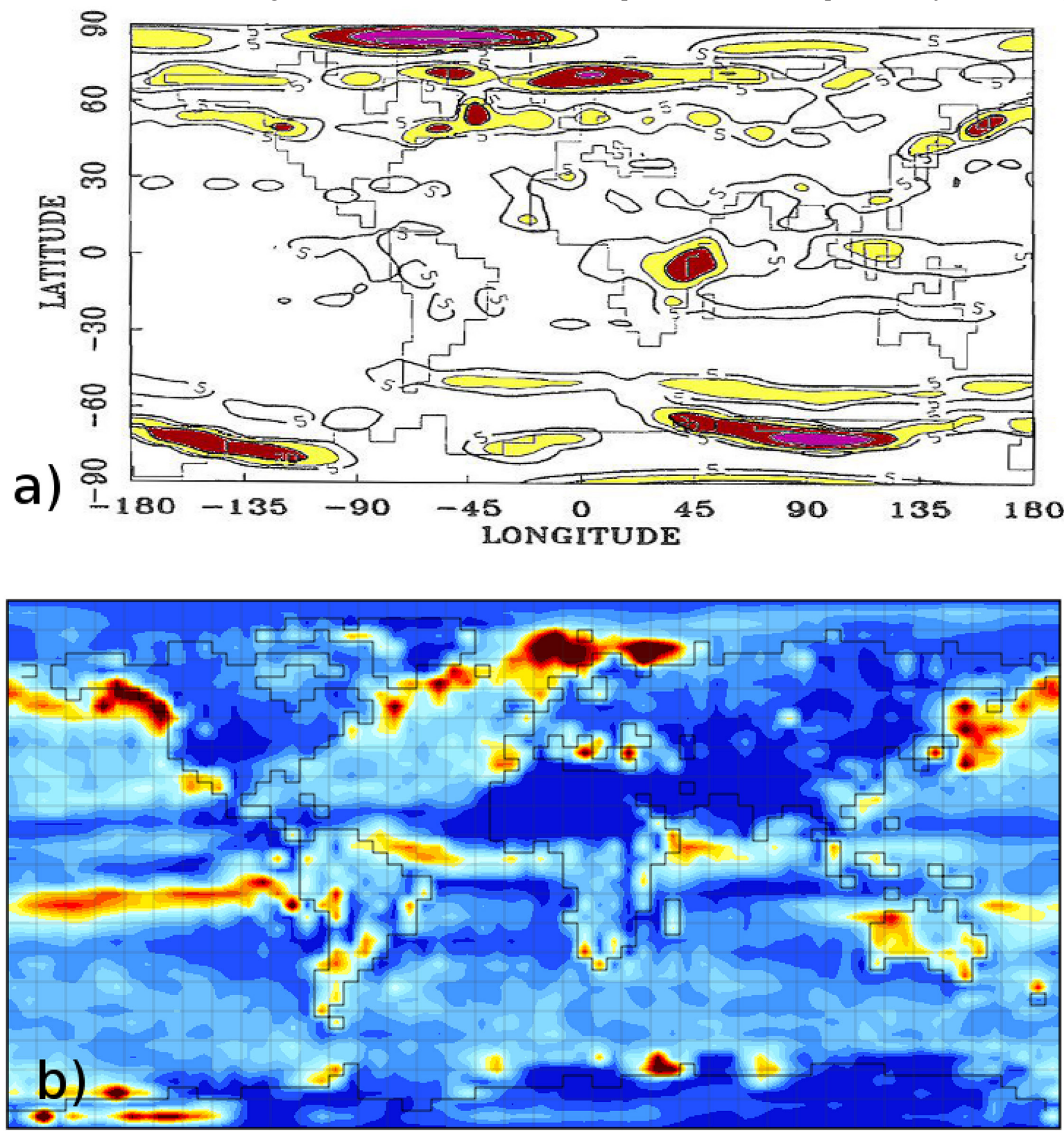

Figure 4. January climate simulations of $30{ }^{\circ} \mathrm{C}$ oceans by a) Spelman and b) Gollmer demonstrate that a warm Arctic Ocean enhances precipitation. A strong contrast between ocean and land temperatures strengthens the thermal circulation. Since the oceans are warmer, the rising air of the thermal circulation as well as the precipitation is over the ocean. In order for an ice sheet to grow, precipitation needs to occur over the cold continent. Therefore, there needs to be a strong global circulation to drive some of this precipitation inland. 
is documented in Schmidt et al. (2014). The model consists of an atmospheric model with a horizontal grid of 144 by $90\left(2.5^{\circ}\right.$ longitude by $2^{\circ}$ latitude; this corresponds to a distance of $278 \mathrm{~km}$ by $222 \mathrm{~km}$ at the equator) and 40 vertical layers extending through the tropopause and stratosphere to a pressure level of $0.1 \mathrm{mb}$. This is coupled with a dynamic ocean model as described in Russell, Miller and Rind (1995). The ocean model has the same horizontal resolution as the atmospheric model and consists of 32 layers extending to a depth of $5 \mathrm{~km}$. Not only does the ModelE2 take into account atmosphere/ocean interactions, but also interactions with land surfaces, land ice and sea ice. When possible, microphysics are incorporated in the calculations, otherwise physical effects are parameterized and then validated through control runs.

When exploring conditions for ice sheet formation, albedo is an important factor. This factor depends on land vegetation, snow cover and the presence of ice on both land and sea. Snow depth and age are accounted for based on surface type and vegetation. Although the elevation of ice sheets in some of the reported simulations are changed, the vegetation type is not. Therefore, bare land after the flood is not taken into consideration and may be a focus of a future study.

A variety of simulations were performed to study the impact of initial and boundary conditions on the location of precipitation and wind patterns needed to initiate ice sheets over the North American continent. Each of these simulations were restricted to six years in order to observe the impact of each change. Although the following discussion and figures are restricted to January values, the model was run and data collected for all seasons and months. The ocean temperatures and circulations were allowed to develop over the six years of simulation. There is some cooling of the Arctic Ocean; however, a more extended run is needed to observe the impact of that change. With this and additional studies it is anticipated that the appropriate conditions needed for ice sheet growth will be determined. At that time a multi-century simulation will be performed to study the rate of growth, areal extent and dynamics of the ice sheet.

In contrast to Gollmer (2013) the ocean temperatures are initialized to a uniform temperature of $24{ }^{\circ} \mathrm{C}$ rather than $30^{\circ} \mathrm{C}$. Although it is found in this study that $24^{\circ} \mathrm{C}$ is still too high, this temperatures was chosen for the following reasons. Ocean temperatures must stay in a range viable for life. At the higher temperature model simulations generated equatorial temperatures reaching $40{ }^{\circ} \mathrm{C}$. Using a marine sediment core Sluijs et al. (2006) reports sea surface temperatures in the arctic of over $23{ }^{\circ} \mathrm{C}$ during the Palaeocene. In contrast to this

\section{Schematic for Global Atmospheric Model}

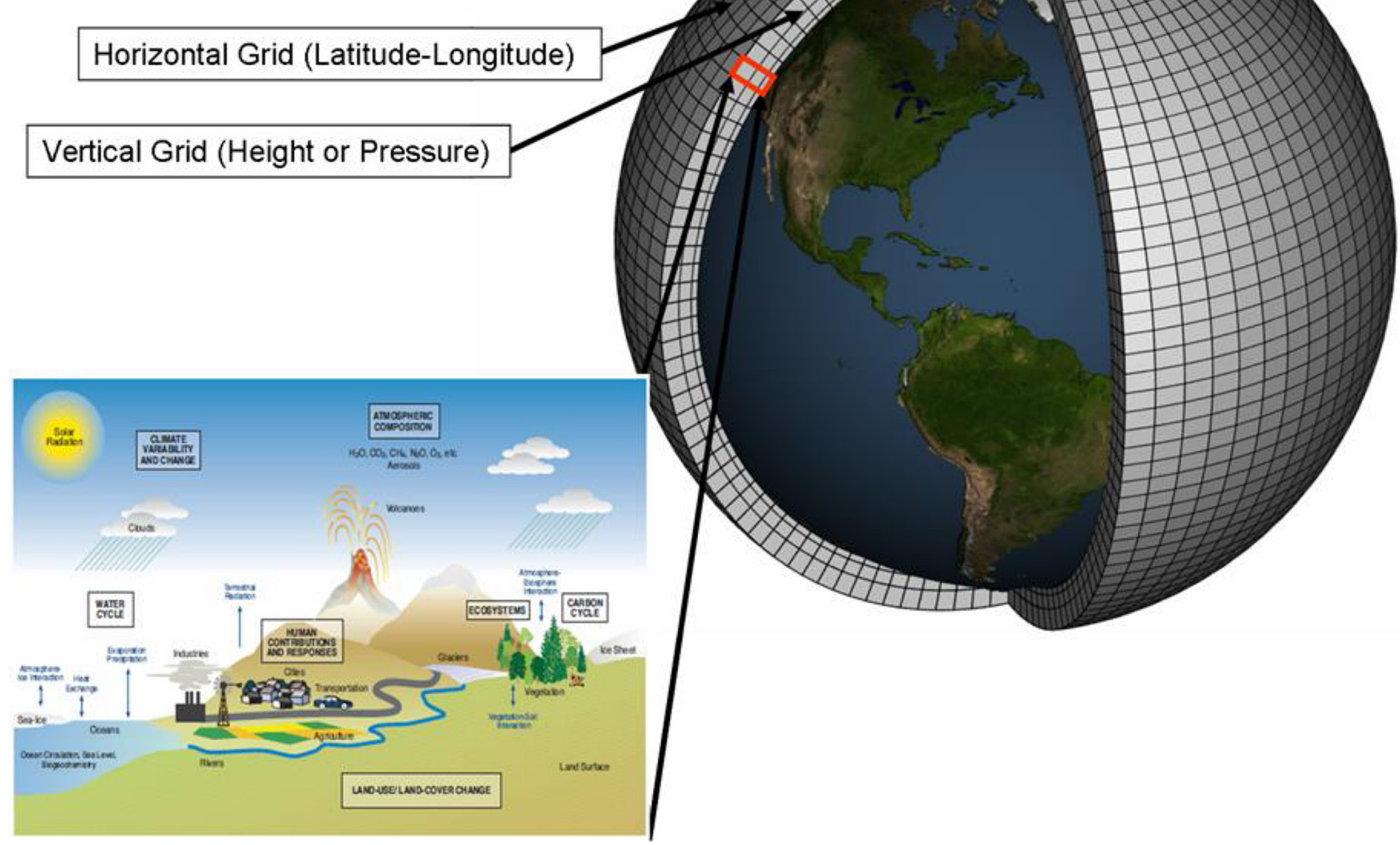

Figure 5. A global climate model simulates weather over large periods of time in order to generate relevant climate statistics. The atmosphere is divided into a grid of cells that cover the earth's surface and extend through the relevant portions of the atmosphere. Equations representing the physical interactions between temperature, pressure, wind, humidity, energy sources and sinks are used to simulate possible outcomes based on initial conditions and boundary conditions. The same process is used to simulate circulations within the ocean (Image is courtesy of NOAA). 
value, Shrag, DePaolo and Richter (1995) provide a reconstructed maximum temperature of $13{ }^{\circ} \mathrm{C}$.

With $24{ }^{\circ} \mathrm{C}$ oceans, global air temperatures became unacceptably high. To offset the additional heat arising from the warm oceans, stratospheric aerosols are added to the atmosphere with various distributions. In the wake of the flood it is also assumed that no ice sheets existed over the continents. This significantly affects the topography of Greenland and Antarctica. Although additional conditions need to be changed to match the post-flood environment, the following simulations were performed:

Reference (Ref) - This reference run uses default initial and boundary conditions linked to a start date of 1900 . Statistically, it should simulate modern day climate conditions.

Warm Oceans (WO) - Beginning with the reference run, the ocean's initial conditions were replaced with a uniform potential temperature of $24{ }^{\circ} \mathrm{C}$. This uniform temperature extends from the equator to the poles and from the surface to the greatest depths. Since the ocean is dynamic, the temperature does not remain uniform, but develops over time. Since the simulation only runs for six years, there is not significant cooling of the oceans, but there is a redistribution of surface temperatures as reported in Gollmer (2013).

Warm Oceans and Stratospheric Aerosols (WOSA) - Adding to the WO simulation, an optically thick aerosol layer is added. Although the aerosols are distributed through several layers of the stratosphere, the net optical thickness has a value of $\tau=2.0$. Optical thickness is tied to the Beer-Lambert Law of transmission, which models intensity as $\mathrm{I}=\mathrm{I}_{0} \mathrm{e}^{-\tau}$. An optical thickness of 2.0 would reduce direct transmission of sunlight to $13.5 \%$ its original value and make the appearance of the sun indistinct in the sky. An aerosol load of this amount is equivalent to a Toba-level volcanic eruption.

Warm Oceans, Stratospheric Aerosols and No Ice (WOSANI) To remove the topographic impact of ice sheets on Greenland and Antarctica, the ice sheets are eliminated. The underlying landmass is exposed and its topography is used. If the ice sheet extends below sea level, it is lowered to sea level, but allowed to remain below this point. This does not account for buoyancy and isostatic rebound of the continents, which involve more significant changes in the boundary conditions. These considerations are saved for a future study. Other than the topographic changes, the conditions of the WOSA simulation are used. Land surface parameters are not changed where the ice sheet is removed; therefore, the albedo of the surface remains unchanged. This should not have a significant impact on the validity of the simulation since any initial buildup of snow and ice would have a similar albedo.

Aerosols, Mid-latitude (AM) - Adding a uniform aerosol layer in the WOSA simulation has an effect on the jet stream, which is tied to storm tracks. Instead of using a uniform layer over the entire earth, a band of stratospheric aerosols are placed between $30^{\circ}$ and $60^{\circ}$ north latitude. Optical thickness of this band is $\tau=2.0$. Other than this change to aerosol distribution, this simulation uses the same conditions as WOSANI.

Aerosols, Polar (AP) - For the same reason the AM simulation is introduced, this simulation restricts the stratospheric aerosols to a band ranging from $45^{\circ}$ to $90^{\circ}$ north latitude. Other than this change, the simulation has the same conditions as WOSANI.

\section{MODEL SIMULATIONS: AEROSOLS AND WIND PATTERNS}

As discussed previously, the position of precipitation patterns depend on several factors. Although global circulation establishes a general pattern, thermal circulation becomes important when there is a temperature contrast between land and ocean. As demonstrated in Vardiman's and Brewer's work, individual weather events can make a significant contribution. However, these patterns are driven by upper-level winds and the position of the polar front, which are connected to the jet stream. These factors play into the behavior of surface winds and the precipitation patterns that ensue. The following is a summary of model comparisons with respect to these issues. Although monthly averages over the course of six simulation years were collected, this discussion will focus only on the last January of the simulation. This month provides the coolest temperatures for the North American continent and will give the best indication of where snowfall is expected.

\section{Thermal Circulation Comparisons}

Figure 6 is a comparison of the temperature and pressure fields for the six simulations mentioned above. Since all except the reference run have warm oceans, the coldest continental temperatures exist in Figure 6a. Temperatures over Greenland are comparable to continental temperatures, but are colder in Figures 6a-c due to the presence of the ice sheet. This is not an albedo effect since this condition was not changed for any of the simulations. This is due, however, to an ice sheet that is up to three kilometers thick.

With air temperatures over land being cold compared to ocean it is expected that high surface pressure would exist over land. This is borne out in each of the simulations. Reducing the pressure field to sea level for sake of comparison, each contour plot represents pressure as a departure from $1000 \mathrm{mb}$, which is close to one atmosphere. Contour lines are drawn in five millibar intervals with pressures below $1000 \mathrm{mb}$ represented as dashed lines. The reference run shows the standard winter pressure pattern. A low pressure system called the Aleutian low is located in the North Pacific. There is a weaker low in the North Atlantic called the Icelandic low.

Adding warm oceans (WO), Figure $6 \mathrm{~b}$, increases the surface temperature everywhere, but more dramatically towards the equator. The Aleutian low expands over a larger region and the Icelandic low is greatly reduced. High pressure is prominent over the Greenland ice sheet. This drives surface winds off land towards the ocean. Adding a uniform layer of aerosols (WOSA), Figure 6c, reduces all temperatures, but also reduces the temperature contrast between the equator and the pole. The Aleutian low in this case splits in two and shifts landward. This is also present in Figure 6d (WOSANI). In the North Atlantic the presence of the Greenland ice sheet provides the highest pressure in Figure $6 \mathrm{c}$, but its absence in Figure 6d greatly reduces the pressure gradient force in this region.

Non-uniform aerosol distributions (AM and AP), in Figures 6e and $\mathrm{f}$ restore the temperature contrast between the equator and 
the pole. Although not displayed in these figures, equatorial and Southern Hemispheric surface temperatures are similar to the WO simulation. The pressure and temperature fields are comparable in Figures 6e and f; however, a general pattern arises when adding a thick aerosol layer. When a thick layer of aerosols is present, the continental temperatures are reduced. However, over the warm Arctic Ocean the surface temperature increases. Solar radiation Surface Air Temperature - Ref

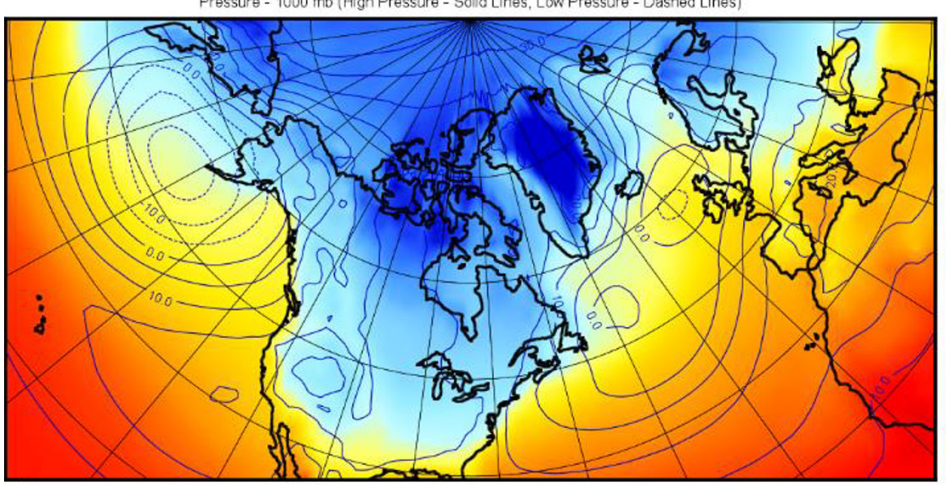

a)

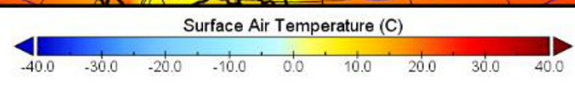

Surface Air Temperature - WOSA

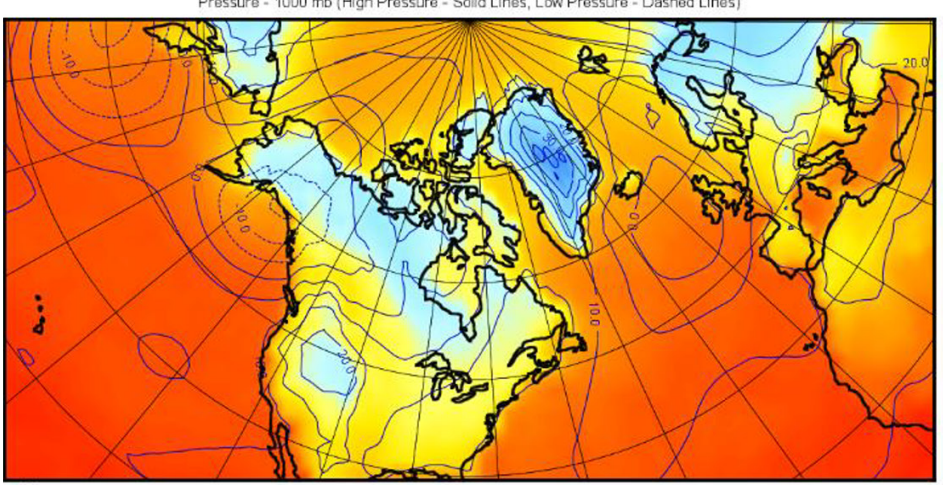

c)

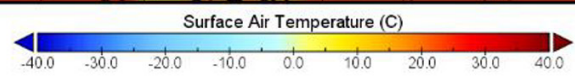

Surface Air Temperature - AM

Pressure - $1000 \mathrm{mb}$ (High Pressure - Solid Lines, Low Pressure - Dashed Lines)

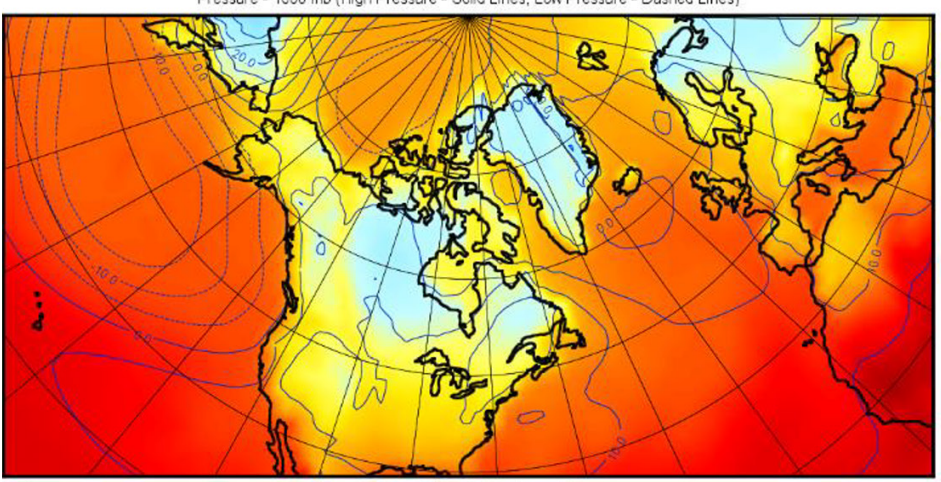

e)

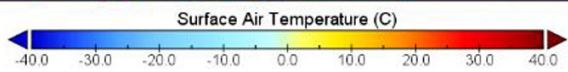

Figure 6. Surface temperature and sea level pressure during January for the following six simulations: a) Reference run b) Warm oceans c) Warm oceans stratospheric aerosols d) Warm oceans stratospheric aerosols and no ice sheets e) Warm oceans with aerosols restricted between $30^{\circ}$ and $60^{\circ} \mathrm{N}$ and f) Warm oceans with aerosols restricted between $45^{\circ}$ and $90^{\circ} \mathrm{N}$. The color key is set so blue represents temperatures below $0{ }^{\circ} \mathrm{C}$ and oranges and reds above freezing. Pressure is represented by contour lines. The plotted pressures are differences from $1000 \mathrm{mb}$. Contours for negative values are represented by dashed lines. is low or nearly absent during the arctic winter; therefore, the only radiative effect that aerosols have is to trap infrared radiation coming from the surface.

\section{Jet Stream Comparisons}

Figure 7 is a comparison of wind speeds at the $250 \mathrm{mb}$ pressure level for the six simulations. Since this level has the strongest winds of the troposphere, it is easier to see the location of the jet

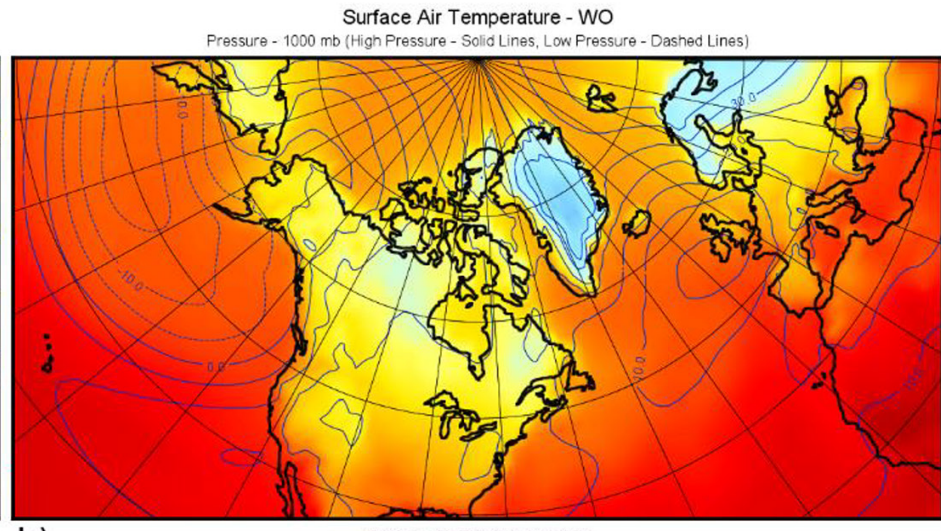

b)
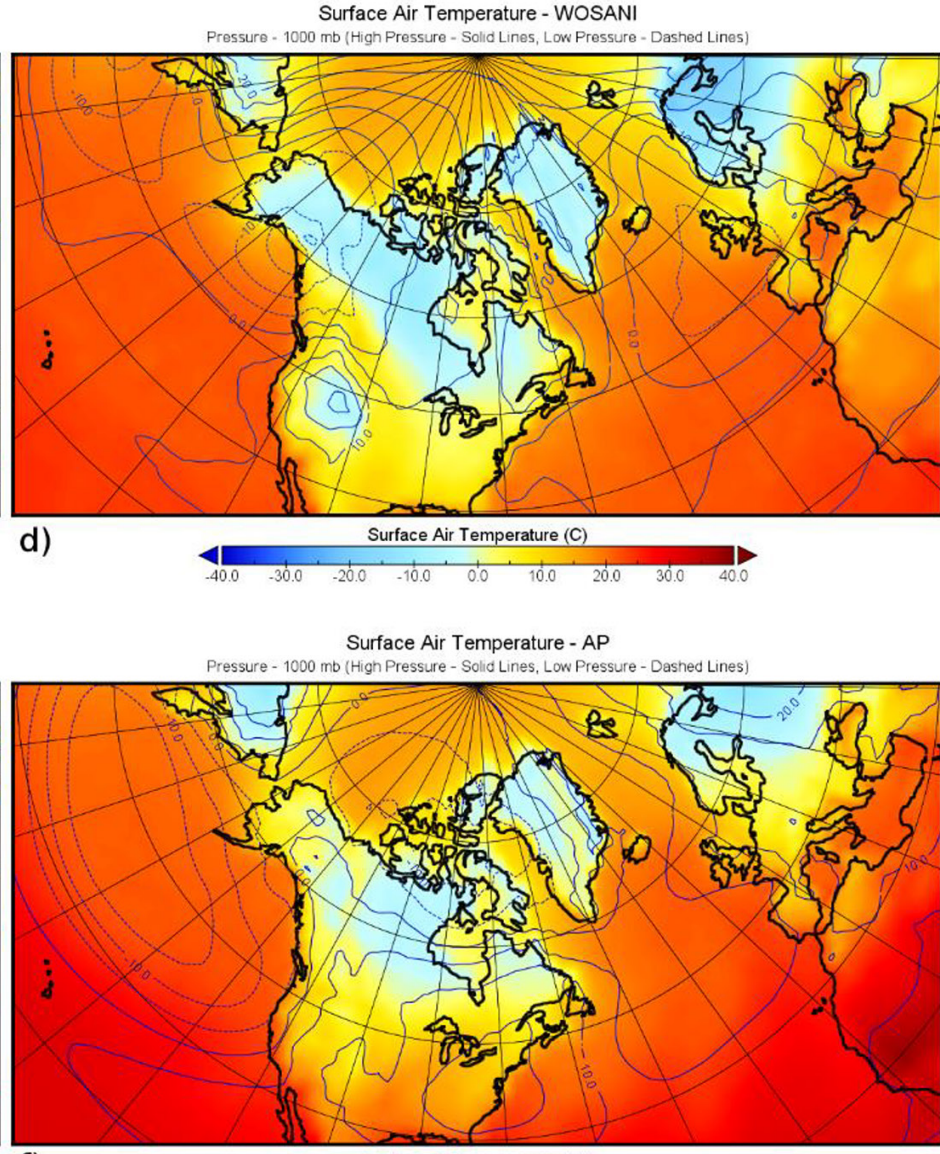

f) 
stream and the associated polar front. A strong jet stream located around $35^{\circ} \mathrm{N}$ is present over the Pacific Ocean in the reference run, Figure $7 \mathrm{a}$. This is also present in the WO simulation, Figure $7 \mathrm{~b}$. However, when a uniform aerosol layer is added, Figures $7 \mathrm{c}$ and $\mathrm{d}$, the jet greatly weakens because the equatorial/polar temperature contrast is reduced. There is a split in the jet, one around $25{ }^{\circ} \mathrm{N}$ and a stronger one at $55^{\circ} \mathrm{N}$. When mid-latitude aerosols (AM) are used, Figure $7 \mathrm{e}$, there is no cooling of the equatorial region thus

Jet Winds - Ref

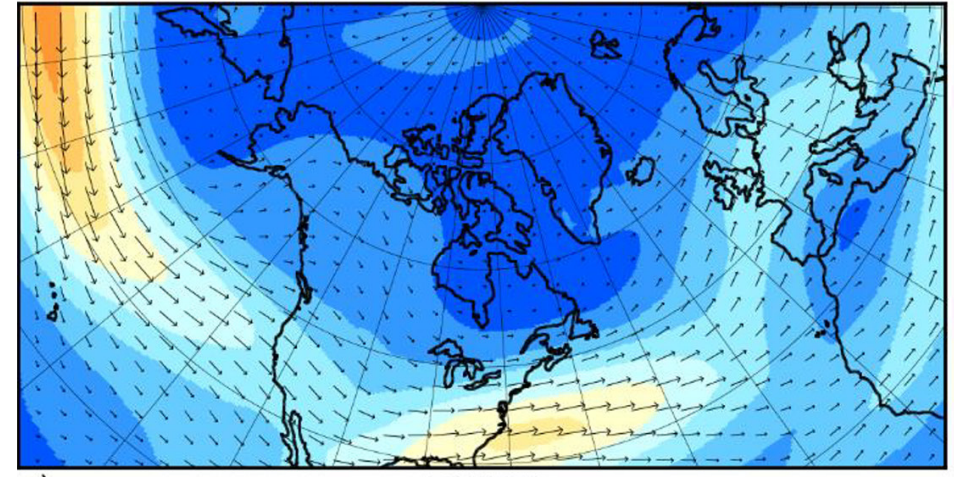

a)

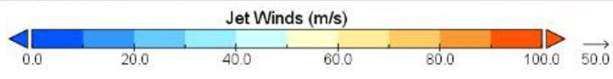

Jet Winds - WOSA

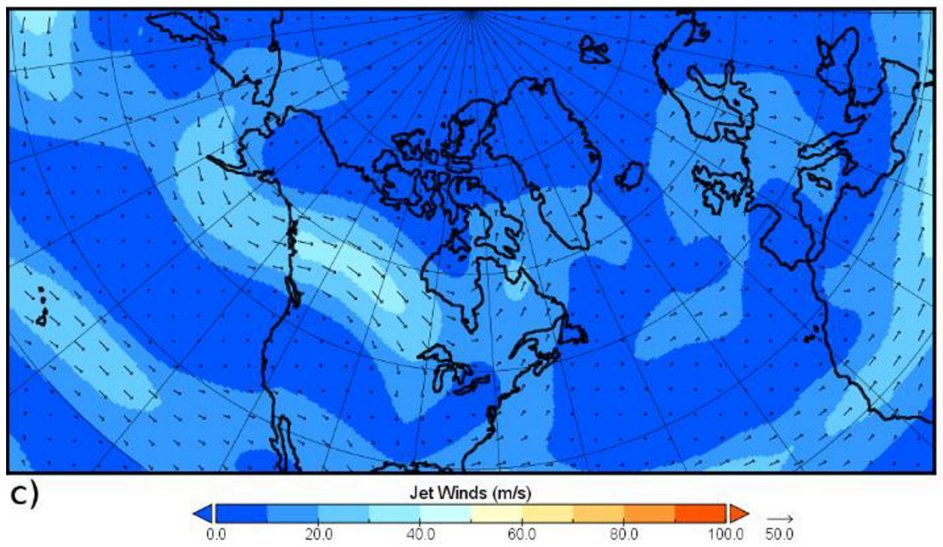

Jet Winds - AM

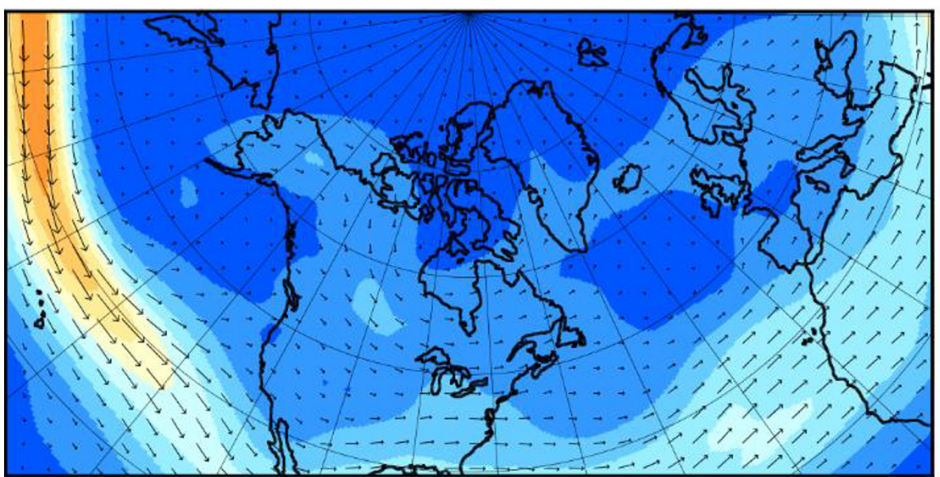

e)

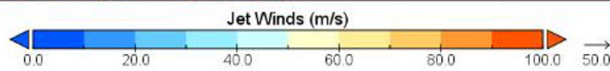

increasing the temperature contrast between the equator and the North Pole. A higher pressure gradient exists at the polar front and the strength of the jet stream is restored to strengths seen in the WO simulation. This is also true of the polar aerosols (PM), Figure $7 \mathrm{f}$. Warm oceans with a uniform aerosol layer greatly reduce the jet steam; however, the rest of the warm ocean simulations (WO, AM and $\mathrm{AP}$ ) result in stronger jet winds compared to the reference run. These jets are also shifted several degrees south in latitude.

Jet Winds - WO

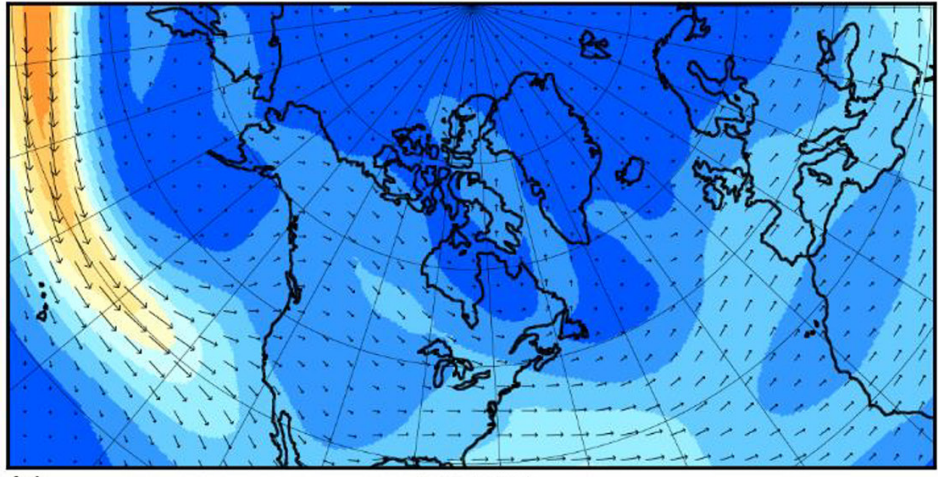

b)

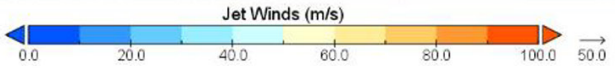

Jet Winds - WOSANI

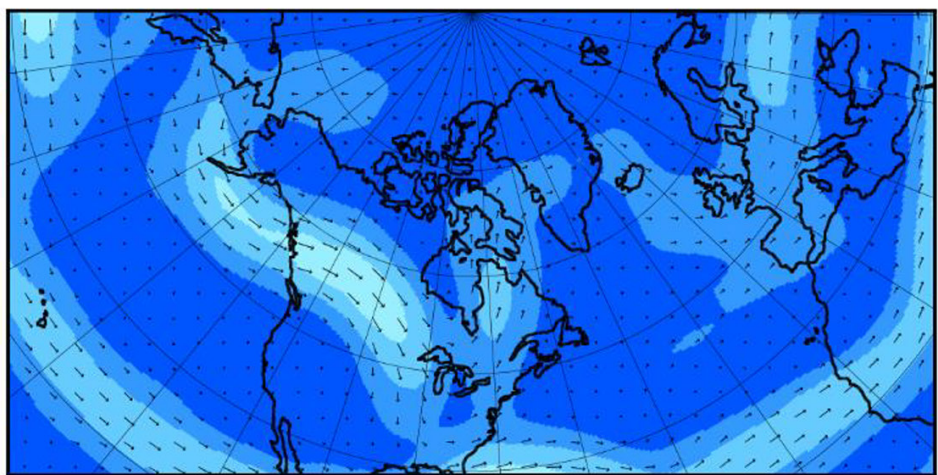

d)

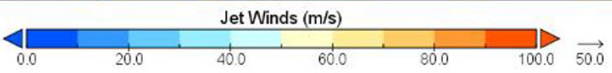

Jet Winds - AP

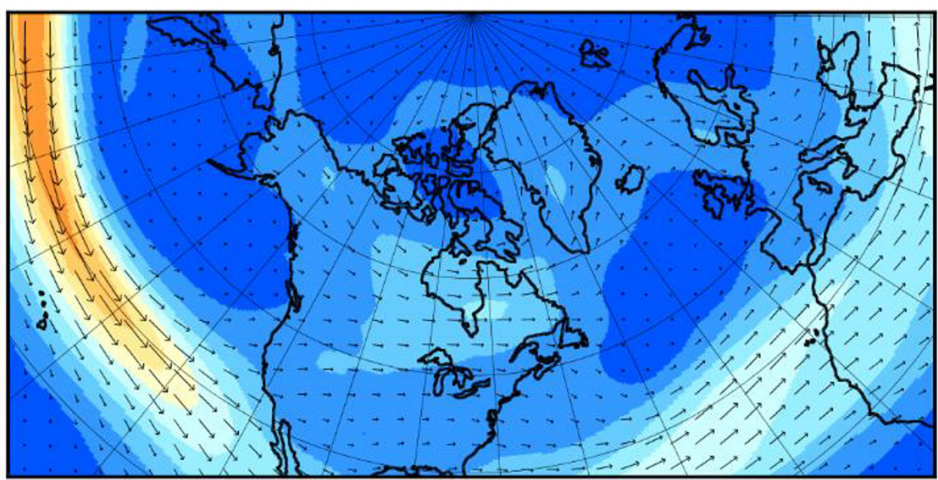

f)

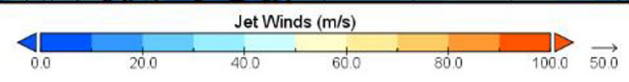

Figure 7. Winds associated with the jet stream during January for the following six simulations: a) Reference run b) Warm oceans c) Warm oceans stratospheric aerosols d) Warm oceans stratospheric aerosols and no ice sheets e) Warm oceans with aerosols restricted between $30^{\circ}$ and $60^{\circ} \mathrm{N}$ and f) Warm oceans with aerosols restricted between $45^{\circ}$ and $90^{\circ} \mathrm{N}$. Wind vectors in these plots correspond to a $250 \mathrm{mb}$ pressure level in the troposphere. Jet streams are linked to the sinking portion of the Ferrel cell (sub-tropical jet) and the rising portion of the Ferrel cell (polar jet). 
Jet steaks of high wind speeds can contribute to the development of surface low pressure systems. This occurs to the left of the transition from high to low speeds. In Figures $7 \mathrm{~b}$, e and $\mathrm{f}$ this exit zone of the streak is between 130 and $140{ }^{\circ} \mathrm{W}$ longitude, which is further east than in the reference run. The jet in the AP simulation, Figure 7f, appears to extend further east and is shifted further to the south.

Precipitation and Surface Winds - Ref

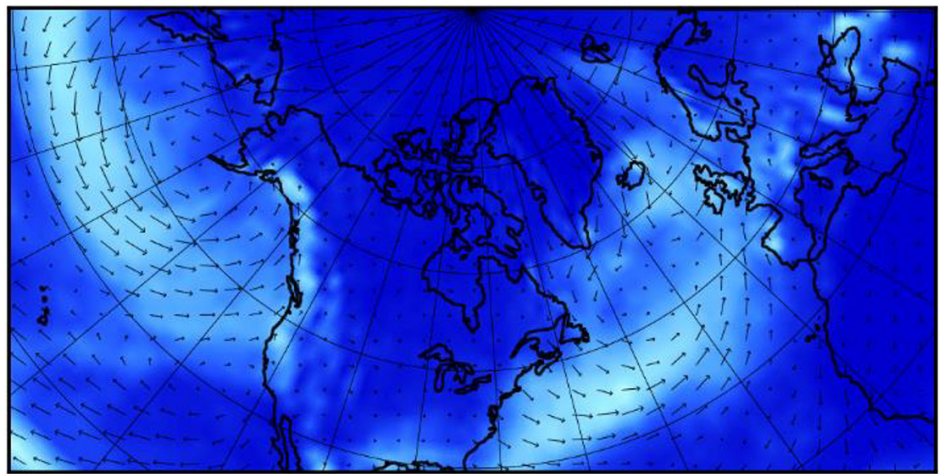

a)

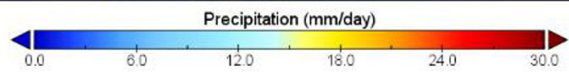

Precipitation and Surface Winds - WOSA

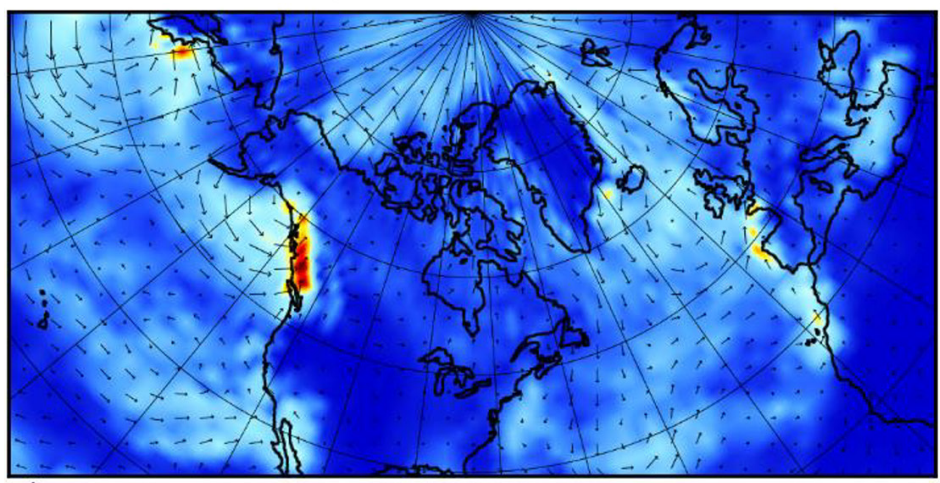

c)

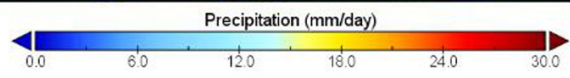

Precipitation and Surface Winds - AM

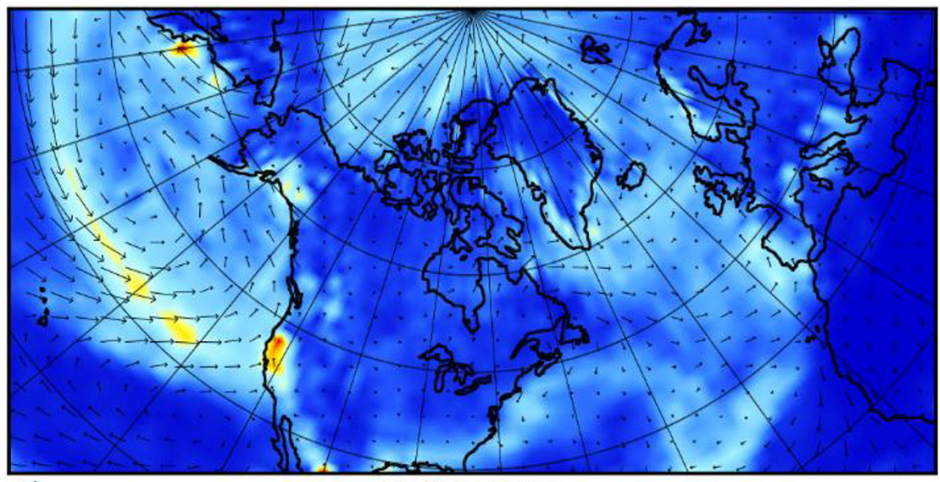

e)

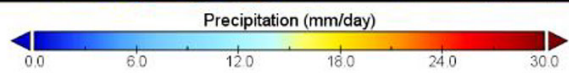

\section{Precipitation Comparisons}

Figure 8 is a comparison of precipitation and surface winds for the six simulations. In all of the simulations with warm oceans, precipitation is enhanced. This is true over the oceans as well as the land. When the Greenland ice sheet is present, Figures $8 \mathrm{~b}$ and c, high pressure prevents precipitation from increasing and the levels are similar to the reference simulation.

The west coast of the North American continent experiences the Precipitation and Surface Winds - wo

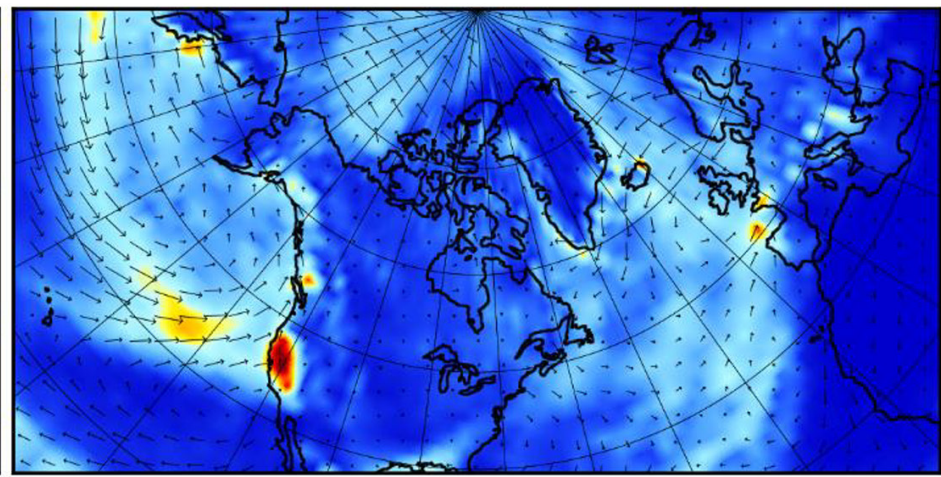

b)

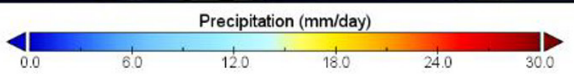

Precipitation and Surface Winds - WOSANI

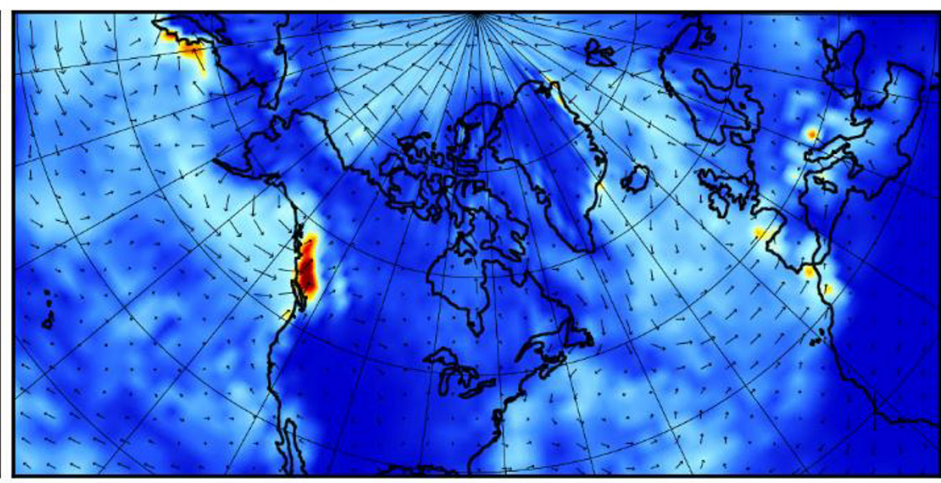

d)

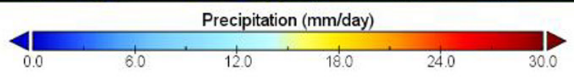

Precipitation and Surface Winds - AP

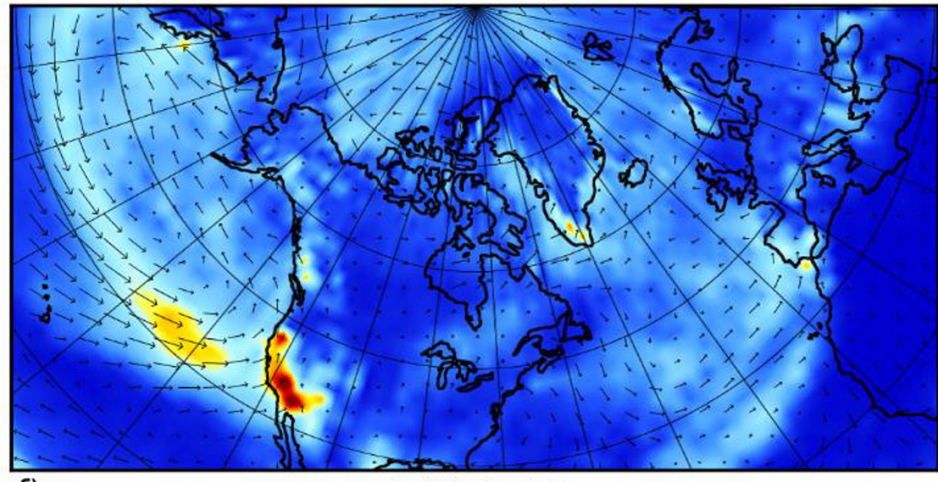

f)
Precipitation (mm/day)

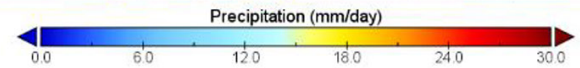

Figure 8. Precipitation and surface winds during January for the following six simulations: a) Reference run b) Warm oceans c) Warm oceans stratospheric aerosols d) Warm oceans stratospheric aerosols and no ice sheets e) Warm oceans with aerosols restricted between $30^{\circ}$ and $60^{\circ} \mathrm{N}$ and f) Warm oceans with aerosols restricted between $45^{\circ}$ and $90^{\circ} \mathrm{N}$. Wind vectors indicate the strength and direction of the surface winds. Regions of high precipitation change based on the conditions of the simulation. 
most intense precipitation. When the jet stream is strong (WO, AM and AP), the precipitation occurs primarily on the United States' coast. There is also higher precipitation near the exit zones of the jet streaks. Since the jet's exit zone is shifted further south and east in Figure 7f (AP), the precipitation maximum also occurs further south in Figure 8f. At first it is surprising that the precipitation in Figure 8e (AM) is weaker than in Figure 8f. However, with midlatitude aerosols in the AM simulation, the surface temperature of the continent is colder than the AP simulation. As a result, there is a land/ocean thermal circulation that weakens the onshore surface winds. When a uniform aerosol layer is used, the jet stream weakens and is split. As a result, Figures $8 \mathrm{c}$ and $\mathrm{d}$ show precipitation maxima shifted northward to the coast of Canada.

All of the warm ocean simulations show an increased precipitation rate over the Great Lakes region and north to Hudson Bay. There does not appear to be a pattern in the surface winds for this region, but the land/ocean temperature difference is smaller thus reducing the thermal circulation. The AP simulation, Figure $8 \mathrm{f}$, shows the largest increase in Ontario, Canada with a precipitation rate of 4 $\mathrm{mm} /$ day. This is an order of magnitude less than the maximum precipitation rate recorded by Spelman (1996). To some extent this is an unfair comparison since Spelman's maximum occurred over the Arctic Ocean.

\section{DISCUSSION}

Six simulations were compared to determine factors that influence the location of precipitation patterns needed to grow an ice sheet over the North American continent. It is clear that warmer oceans increase the precipitation rate in arctic regions, but this precipitation primarily falls on open water. The ice sheet over Greenland hinders precipitation over land due to a strong thermal circulation. This is lessened when it is removed. However, this illustrates the challenge of maintaining high precipitation rates over a continental ice sheet once it is formed.

Uniformly distributed stratospheric aerosols offset the higher surface temperatures generated by warm oceans. However, a uniform equator to pole aerosol distribution reduces the north/ south temperature contrast and likewise reduces the strength of the jet stream. Aerosols restricted to the mid-latitudes or Polar Regions restore the temperature contrast and strength of the jet stream, but these two distributions have only a small impact on the location of the jet stream. In the Ferrel cell winds are westerlies. These winds along with a strong jet stream and a weak land/ocean thermal circulation result in strong precipitation along the western coast of the United States. This result is compatible with results reported by Vardiman and Brewer (2010a, b, c).

In the North Atlantic the polar easterlies do not penetrate into Eastern Canada. There is a weak thermal circulation that keeps most of the precipitation over the ocean. Although the Icelandic low could potentially affect surface winds in North America, it is shifted east and has a more significant effect on Western Europe. Aerosols restricted to the Polar Regions have the largest impact on precipitation near the Great Lakes and southeast Canada; however, the rates are an order of magnitude smaller than desired for a rapid growth of an ice sheet. Because surface temperatures are higher due to the warm oceans, these simulations give marginal conditions for snowfall. Most likely it would be a mix of snow and rain. Since this is the heart of winter, precipitation the rest of the year would be rain.

Although aerosol distribution has an effect on the jet stream, surface winds and precipitation; this is minor compared to the global circulation and land/ocean thermal circulations. If an ice sheet is to form, the most significant factor is surface temperature. A non-uniform aerosol distribution is preferable over a uniform distribution, but to control temperature it is necessary to consider even thicker aerosol layers. In addition, water temperature in the Arctic Ocean needs to be cooler to reduce the strength of the thermal circulation. This might make it possible for circulation in the polar cell to draw humid air into the Hudson Bay region. A longer simulation would allow considerable cooling of the Arctic Ocean and test this hypothesis.

Future work needs to focus on reducing surface temperature in the presence of warm oceans. Thicker aerosol layers can be tried, but it appears that cooler surface temperatures in the Arctic Ocean are a reasonable next step. Since the GISS ModelE2 has a dynamic ocean, the next simulation should run for a century or more to study how the temperature profile of the ocean changes with time. Since the time constant for a deeply circulating ocean is about 40 years, this simulation should transition the ocean from a uniform temperature of $24{ }^{\circ} \mathrm{C}$ to a temperature distribution that is within $10 \%$ of modern day equilibrium values. Such a simulation would also reveal how circulation patterns shift with oceanic cooling.

\section{CONCLUSION}

The GISS ModelE2 was used to study the impact of aerosol location on precipitation patterns. Six simulations were compared to determine what factors might contribute to the development of an ice sheet over the North American continent. As seen in other studies, warmer oceans result in increased precipitation in arctic regions. However, this precipitation primarily falls on open water. Although aerosol distribution has an effect on precipitation patterns, this is minor compared to the global circulation and land/ ocean thermal circulations. Non-uniform aerosol distributions are advantageous for a strong jet stream since they maintain a larger temperature contrast between the equator and the North Pole. It is clear that a combination of thicker aerosol layers and a cooler Arctic Ocean is needed to establish surface air temperatures cold enough for snow accumulation.

\section{ACKNOWLEDGMENTS}

A number of people and organizations have been instrumental to the success of this work. Central to this work is the GISS ModelE2. Development of this code is ongoing and coordinated through the NASA Goddard Institute for Space Studies. When resolving issues related to changed boundary conditions, the GISS data archive and personal communication with Dr. Gavin Schmidt were invaluable. Data plots were generated using the Panoply Data Viewer, which is under continued development by Dr. Robert Schmunk. Computer resources were provided by Cedarville University and the Ohio Supercomputer Center. The Creation Geological Society provided a forum for presenting preliminary work leading to this publication.

\section{REFERENCES}

Agassiz, L. 1840. Etudes sur les glaciers, Reissue edition (2012). 
New York: Cambridge University Press.

Brayshaw, D.J., B. Hoskins, and M. Blackburn 2009. The basic ingredients of the North Atlantic storm track. part I: land-sea contrast and orography. Journal of the Atmospheric Sciences 66:2539-2558.

Buckland, W. 1858. Geology and mineralogy considered with reference to natural theology, Third edition. London: R. Clay Printer.

Gollmer, S.M. 2013. Initial conditions for a post-flood rapid ice age. In Proceedings of the Seventh International Conference on Creationism, ed. M.F. Horstemeyer. Pittsburgh, Pennsylvania: Creation Science Fellowship.

Hansen, J. et al. 1983. Efficient three-dimensional global models for climate studies: Models I and II. Monthly Weather Review 111:609-662.

Lyell, C. 1833. Principles of geology: or, the modern changes of the earth and its inhabitants considered as illustrative of geology. Salt Lake City: Project Gutenberg Literary Archive Foundation.

Mortenson, T. 2004. The great turning point. Green Forest, Arizona: Master Books.

Oard, M.J. 1979. A rapid post-flood ice age. Creation Research Society Quarterly 16, no. 1 (June):29-37.

Oard, M.J. 1990. An ice age caused by the Genesis Flood. El Cajon, California: Institute for Creation Research.

Price, G.M. 1923. The new geology: a textbook for colleges, normal schools, and training schools; and for the general reader. Mountain View, CA: Pacific Press Publishing Assoc.

Robertson, A., et al. 2001. Hypothesized climate forcing time series for the last 500 years. Journal of Geophysical Research 106:14783-14803.

Robock, A., et al. 2009. Did the Toba volcanic eruption of $\sim 74 \mathrm{ka}$ B.P. produce widespread glaciation? Journal of Geophysical Research 114:D10107.

Russell, G.L., J.R. Miller, and D. Rind 1995. A coupled atmosphereocean model for transient climate change studies. AtmosphereOcean 33:683-730.

Schmidt, G.A., et al. 2014. Configuration and assessment of the GISS ModelE2 contributions to the CMIP5 archive. Journal of Advances in Modeling Earth Systems 6:141-184.

Schrag, D.P., D.J. DePaolo, and F.M. Richter 1995. Reconstructing past sea surface temperatures: correcting for diagenesis of bulk marine carbonate. Geochimica et Cosmochimica Acta 59:22652278.

Sluijs, A., et al. 2006. Subtropical Arctic Ocean temperatures during the Palaeocene/Eocene thermal maximum. Nature 441:610-613.
Spelman, K.E. 1996. A Sensitivity study of the post-flood climate using the NCAR CCM1 model with a warm sea-surface temperature. ICR Thesis, El Cajon, California: ICR Graduate School.

Vardiman, L. 1998. Numerical simulation of precipitation induced by hot mid-ocean ridges, In Proceedings of the Fourth International Conference on Creationism, ed. R.E. Walsh, pp. 595-605. Pittsburgh, Pennsylvania: Creation Science Fellowship.

Vardiman, L. 2003. Hypercanes following the Genesis flood. In Proceedings of the Fifth International Conference on Creationism, ed. R.L. Ivey, pp. 17-28. Pittsburgh, Pennsylvania: Creation Science Fellowship.

Vardiman, L. and W. Brewer. 2010a. Numerical simulation of precipitation in Yosemite National Park with a warm ocean: a pineapple express case study. Answers Research Journal 3:2336.

Vardiman, L., and W. Brewer. 2010b. Numerical simulation of precipitation in Yosemite National Park with a warm ocean: deep upper low and rex blocking pattern case studies. Answers Research Journal 3:119-145.

Vardiman, L., and W. Brewer. 2010c. Numerical simulation of precipitation in Yosemite National Park with a warm ocean: continuous zonal flow, Gulf of Alaska low, and plunging western low case studies. Answers Research Journal 3:209-266.

Vardiman, L., and W. Brewer. 2011. A well-watered land: numerical simulations of a hypercyclone in the Middle East. Answers Research Journal 4:55-74.

Vardiman, L., and W. Brewer. 2012a. Numerical simulation of hypercanes Charley and Fay in the Caribbean and the Gulf of Mexico over a warm ocean. Answers Research Journal 5:13-24.

Vardiman, L., and W. Brewer. 2012b. Numerical simulation of three nor'easters with a warm Atlantic Ocean. Answers Research Journal 5:39-58.

Whitcomb, J.C. and H.M. Morris. 1961. The Genesis flood: the biblical record and its scientific implications. Grand Rapids, Michigan: Baker Book House.

\section{THE AUTHOR}

Dr. Gollmer serves as professor of physics at Cedarville University. He earned a B.S. in secondary education, math and science from Pillsbury Baptist Bible College, a B.S. in physics from Northern Illinois University, an M.S. in physics from the University of Illinois and a Ph.D. in atmospheric science from Purdue University. He is a member of the Creation Research Society, Creation Biology Society, American Geophysical Union and American Association of Physics Teachers. Dr. Gollmer's specialization includes wavelet analysis, Monte Carlo simulation and radiative transfer. His research is currently focused on climate modeling and data science. 